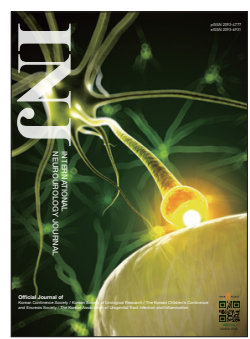

\title{
Sling Surgery for Male Urinary Incontinence Including Post Prostatectomy Incontinence: A Challenge to the Urologist
}

\author{
Kwang Jin Ko, Sung Jin Kim, Sung Tae Cho \\ Department of Urology, Hallym University Kangnam Sacred Heart Hospital, Hallym University College of Medicine, Seoul, Korea
}

\begin{abstract}
The management of postprostatectomy urinary incontinence (PPI) is still challenging for urologists. In recent decades, various kinds of male sling system have been developed and introduced; however, they have not yet shown as good a result as that of artificial urinary sphincter (AUS). However, a male sling is still in an important position because patients have a high demand for sling implantation, and it can allow the avoidance of the use of mechanical devices like AUS. Recently, the male sling has been widely used in mild-to-moderate PPI patients; however, there are no studies that compare individual devices. Thus, it is hard to directly compare the success rate of operation, and it is impossible to judge which sling system is more excellent. It is expected that many sling options will be available in addition to AUS in the near future with the technological development of various male slings and the accumulation of long-term surgical outcomes. In that in patients with PPI, sling implantation is an option that must be explained rather than an option that need not be explained to them, this review would share the latest outcomes and complications.
\end{abstract}

Keywords: Suburethral sling; Postprostatectomy incontinence; Stress urinary incontinence

- Conflict of Interest: No potential conflict of interest relevant to this article was reported.

\section{INTRODUCTION}

Male stress urinary incontinence (SUI) is reported to occur in $1 \%-60 \%$ of patients following radical prostatectomy $[1,2]$. To date, artificial urinary sphincter (AUS) implantation has been the standard treatment. However, the AUS has several limitations, including in the long-term necessity for revisions due to either mechanical failure or urethral atrophy [3].

The concept of the male sling was first introduced by Berry in the 1970s and then developed by Kaufman and Schaefer resulting in the current male sling used in clinical practice today [3-5]. Male slings can be divided broadly into the noncompressive, repositioning type retrourethral transobturator sling and com- pressive, and adjustable type. This review article aimed to conduct comparative analysis, based on current literature, of the strength of each sling type in order to aid urologists in the treatment of patients who cannot have an AUS device implanted.

\section{TRANSOBTURATOR RETROURETHRAL SLING}

\section{AdVance and AdVance XP}

The AdVance sling (Boston Scientific, Marlborough, MA, USA) was introduced in 2007 and is a retrourethral sling that contains polypropylene mesh. It is positioned under the membranous urethra via a transobturator approach. To position the sling accurately, it is necessary to detach the central tendineum. Then,

Corresponding author: Sung Tae Cho (D https://orcid.org/0000-0002-4691-6159 Department of Urology, Hallym University Hallym University Kangnam Sacred Heart Hospital, Hallym University College of Medicine, 1 Singil-ro,

Yeongdeungpo-gu, Seoul 07441, Korea

E-mail: cst326@paran.com / Tel: +82-2-846-5326 / Fax: +82-2-846-5198

Submitted: June 17, 2019 / Accepted after revision: August 2, 2019 
the mesh is fixed to the bulbous urethra, and the tension is adjusted so that the membranous urethra can be relocated to a further proximal position, which ultimately causes the relocation of the structure supporting the urethra to the state it was in prior to prostatectomy.

The definitions of cure and improvement and follow-up time differ depending on the study, but the overall cure rate is $46 \%$ $74 \%$, while the improved rate is $13 \%-26 \%$ (Table 1) [6-18]. summarized efficacy and complications following the Advance male sling. In 2011, Cornu et al. [9] reported that the cure rate of AdVance sling after a 3-year follow-up was 61.8\%, and its improved rate was $16.2 \%$. This study defined 'cure' as no pad usage and 'improvement' as a decreased in pad use of $>50 \%$. Another study reported by Rehder et al. [11] defined cure as no pad or 1 dry pad for security reasons and improvement as 1 or 2 pads per day and if there was a reduction in daily pad usage of $50 \%$. In the 3-year follow-up of 156 , the cure rate was similar at $53.8 \%$ in 12 months and 53.0\% in 3 years. However, according to other reports of long-term outcomes, the success rate gradually decreased ( $74 \%$ at 1 year, $63 \%$ at 2 years, and $62 \%$ at 3 years). It was reported that the no pad cure rate was $40 \%$ [19].

Several urodynamic studies suggest that the AdVance sling does not cause obstruction to the urethra. Davies et al. [20] reported that Valsalva leak point pressure significantly improved by 6 months after AdVance insertion, while no changes oc- curred in the detrusor voiding pressure, postvoid residual urine volume, and maximal and average flow rates. A subsequent study assessed urodynamic parameters after AdVance sling insertion and found that no patient showed postvoided residual urine $30 \mathrm{~mL}$, de novo reduced bladder compliance, or de novo hypo- or overactivity. No obstruction (bladder outlet obstruction index $<20)$ was seen in 35 patients $(63.6 \%)$ preoperatively and 42 patients (76.3\%) postoperatively [5]. Subsequent studies also reported that transient urinary retention was increased to about $2 \%-23.5 \%$; however, this complication spontaneously resolved within 4-12 weeks $[7,8,10,11,13,16,21]$.

In 2010, AdVance XP (Boston Scientific) was newly launched. Better stability was provided by tensioning fibers, chevron anchors and Tyvek (DuPont, Wilmington, DE, USA) liners and the implantation needle was modified to facilitate implantation. However, there were no changes made to the mechanism or operation method [22]. According to an earlier study, it was reported that the cured or improved rate was superior in the AdVance XP group ( $90.3 \%$ vs. $69.3 \%$ ). In obese patients at maximum follow-up, the AdVance showed a remarkably good surgical result ( $90.5 \%$ vs. $45.0 \%)$. The authors mention that the new anchor is superior for the fixation of the sling, and accordingly, for the avoidance of sling slippage or early sling loosening. They also noted that these effects may be more substantial in obese patients [15]. However, in a study published recently, no

Table 1. Summary of efficacy and complications following the advance male sling

\begin{tabular}{|c|c|c|c|c|c|c|c|}
\hline $\begin{array}{l}\text { Reference } \\
\text { No. }\end{array}$ & No. & $\begin{array}{l}\text { Follow-up } \\
\quad(\mathrm{mo})\end{array}$ & Definition of cure & $\begin{array}{c}\text { Cure } \\
\text { rate }(\%)\end{array}$ & $\begin{array}{l}\text { Definition of } \\
\text { improvement }\end{array}$ & $\begin{array}{l}\text { Improvement } \\
\text { rate }(\%)\end{array}$ & Complication \\
\hline [6] & 102 & 13 & $\begin{array}{l}\text { No pad usage or one pad } \\
\text { for security reasons }\end{array}$ & 62.7 & A reduction of pads $50 \%$ & 17.6 & No complications \\
\hline [7] & 118 & 12 & No pad usage & 73.7 & A reduction of pads $50 \%$ & 16.9 & $\begin{array}{l}19.5 \% \text { : transient scrotal pain } \\
\text { or perineal discomfort } \\
5.1 \% \text { : transient urinary } \\
\text { retention } \\
1.7 \% \text { : adductor pain }\end{array}$ \\
\hline [9] & 136 & 36 & No pad usage & 61.8 & A reduction of pads $50 \%$ & 16.2 & $\begin{array}{l}10 \% \text { : perineal pain } \\
14 \% \text { : mild dysuria }\end{array}$ \\
\hline$[11]$ & 156 & 39 & $\begin{array}{l}\text { No pad usage or one pad } \\
\text { for security reasons }\end{array}$ & 53.0 & $\begin{array}{l}\text { One or } 2 \text { pads per day were } \\
\text { used and if there was a } \\
\text { reduction of pads } 50 \%\end{array}$ & 23.8 & $\begin{array}{l}50 \% \text { : mild perineal pain } \\
\text { 9\%: transient urinary } \\
\text { retention }\end{array}$ \\
\hline$[12]$ & 55 & 12 & No pad usage & 47.0 & A reduction of pads $50 \%$ & 26.0 & $\begin{array}{l}23.6 \% \text { : transient urinary } \\
\text { retention }\end{array}$ \\
\hline$[15]$ & 39 & 24.7 & No pad usage & 46.2 & A reduction of pads $50 \%$ & 23.1 & 5.1\%: urinary urgency \\
\hline$[16]$ & 31 & 39 & No pad usage & 58.1 & A reduction of pads $50 \%$ & 12.9 & $\begin{array}{l}\text { 30\%: transient urinary } \\
\text { retention }\end{array}$ \\
\hline
\end{tabular}


differences were found between the AdVance and AdVance XP following validated questionnaires (e.g., International Consultation on Incontinence Questionnaire (ICIQ)-Short Form, Incontinence-Quality of Life, and Patient Global Impression-Improvement [PGI-I]), the number of pads used during the follow-up, and unlike the existing studies, urinary retention occurred significantly more often in patients with the AdVance XP, affecting $10.3 \%$ of the patients [18]. AdVanceXP has been launched as the second generation; however, it is necessary to evaluate the device to determine whether it is superior to the AdVance, according to further outcomes.

Identifying the risk factors for surgical failure would help with preoperative decision-making and counseling. Several studies made efforts to evaluate related factors. The severity of the baseline incontinence may affect the outcome. In patients in whom more than $200 \mathrm{~g}$ was found per day in a 24-hour pad test, the success rate of surgery was significantly low $[9,13,16]$. Collado Serra et al. [13] reported that the cure rate decreased by $0.4 \%$ with the increase of $1 \mathrm{~g}$ in a 24 -hour pad test, presenting the correlation between the preoperative degree of incontinence and surgical outcome. Furthermore, patients in whom more than $400 \mathrm{~g}$ were found in a 24-hour pad test had $80 \%$ lower possibility than those in whom more than $200 \mathrm{~g}$ were found did. Overall, the male sling technique is not considered an appropriate treatment method in patients with severe baseline incontinence.

Studies have indicated that prior radiation exposure is a risk factor for surgical failure. Although studies have found no direct correlation $[9,16]$, in large-scale research, prior radiation treatment is associated with the increased risk in sling failure $[6,14,17]$. Torrey et al. [14] conducted a comparative analysis of patients with previous radiation treatment and those without, in a retrospective study. No previous radiation patients were cured and only $28.6 \%$ showed improvement, while $63.3 \%$ of the group of patients with no previous radiation treatment were cured, and $26.7 \%$ showed improvement. Along with direct damage to the sphincter by radiation, ischemia occurs in the irradiated tissue, and as the rigidity of the tissue increases, the decrease of mobility is considered the cause for worse outcomes due to radiation treatment.

\section{TOMS/I-STOPTOMS}

I-STOP TOMS (CL Medical, Lyon, France), which consists of the 4-arm transobturator male sling, is an adapted version of the 2-arm TOMS. The classical implantation procedure consists of a vertical perineal incision followed by exposure of the bulbospongious muscle, without dissecting the central tendon. The bulbar urethra is not detached from the perineum and urethral repositioning does not occur. The sling is placed over the muscle and compresses at the bulbous urethra by suspending through the transobturator foramen.

In TOMS patients with mild-to-moderate incontinence, 30\% were reported to be pad-free 3 months after the sling operation. Furthermore, short-form-36 scores and ICIQ scores improved in all patients compared to baseline. The median maximal flow rate was $20 \mathrm{~mL} / \mathrm{sec}$ before surgery and $16 \mathrm{~mL} / \mathrm{sec}$ after surgery, with no significant aggravation during the follow-up [23]. Yiou et al. [24,25] prospectively analyzed the urinary symptoms of 40 patients who had TOMS and announced the result of a 2-year follow-up. Seven of the 40 patients needed additional surgical treatment (5 had ProACT balloon while 2 had AUS). In the remaining patients, the cure rate at 24 months was $45.5 \%$, and there were significant improvements of symptoms in the ICIQ and PGI-I scores based on the baseline. It was also found that the average pad usage significantly improved.

According to a prospective, multicenter study that followed patients for at least 12 months after the implementation of ISTOP TOMS, 59\% of 122 patients were cured (dry) while $87 \%$ showed improvement. No acute urinary retention or mesh erosion occurred; however, wound infection occurred in $2 \%$ of patients, therefore, the sling was removed [26]. There is one longterm study of a median 59-month follow-up available, and the dry rate of 100 patients with mild-to-moderate incontinence (24-hour pad test $<400 \mathrm{~g}$ ) after the implementation of the ISTOP TOMS implant showed a decrease from $40 \%$ in 1 year to $15 \% 5$ years after the surgery, so the long-term treatment effect does not appear to be good [27]. Recently, a new technique of placing the I-STOP TOMS sling on the superficial fascia was introduced. Of the 34 patients who could be followed up for 1 year, $52.9 \%$ were pad-free while $73.5 \%$ showed improvement. Two times of implantation were conducted choose to revise with 5 patients in the same technique, and the strict continent rate was $100 \%$ in 6 months and $100 \%$ in 12 months, so it is suggested as an option to salvage procedures [28]. Table 2 summarized efficacy and complications following the TOMS and ISTOP TOMS.

\section{Virtue Sling}

The Virtue quadratic sling (Coloplast, Humlebæk, Denmark) is a device for treating postprostatectomy urinary incontinence 
Ko, et al. • Sling Surgery for Male Urinary Incontinence

Table 2. Summary of efficacy and complications following the TOMS and I-STOP male sling

\begin{tabular}{|c|c|c|c|c|c|c|c|c|}
\hline $\begin{array}{l}\text { Reference } \\
\text { No. }\end{array}$ & Device & No. & $\begin{array}{l}\text { Follow-up } \\
(\mathrm{mo})\end{array}$ & $\begin{array}{l}\text { Definition } \\
\text { of cure }\end{array}$ & $\begin{array}{c}\text { Cure } \\
\text { rate }(\%)\end{array}$ & $\begin{array}{l}\text { Definition of } \\
\text { improvement }\end{array}$ & $\begin{array}{l}\text { Improvement } \\
\text { rate }\end{array}$ & Complication \\
\hline$[23]$ & TOMS & 50 & 12 & None or one PPD & 32 & - & - & $\begin{array}{l}2 \% \text { : urinary retention } \rightarrow \\
\text { release the tension (day } 2 \text { ) }\end{array}$ \\
\hline$[24]$ & TOMS & 40 & 12 & None or one PPD & 55 & $\begin{array}{l}\leq 2 \text { pads/day and a } \\
\text { reduction of pads } 50 \%\end{array}$ & 32.5 & $\begin{array}{l}\text { No major complications } \\
\text { No case of prolonged } \\
\text { perineal pain }\end{array}$ \\
\hline$[25]$ & TOMS & 33 & 24 & None or one PPD & 45.5 & - & - & No major complications \\
\hline [26] & I-STOP & 103 & 12 & None or one PPD & 79.7 & - & - & No major complications \\
\hline$[27]$ & I-STOP & 100 & 58 & None or one PPD & 77 & - & - & No major complications \\
\hline$[28]$ & I-STOP & 34 & 12 & None or one PPD & 82.4 & $\begin{array}{l}\text { A reduction of } \\
\text { pads } 50 \%\end{array}$ & 7.5 & $\begin{array}{l}2.9 \% \text { : transient urinary retention } \\
2.9 \% \text { : wound infection } \\
14.7 \% \text { : ecchymosis without } \\
\text { compression }\end{array}$ \\
\hline
\end{tabular}

PPD, pad per day.

(PPI) consisting of a monofilament polypropylene mesh with 2 preattached transobturator arms providing proximal urethral relocations and 2 prepubic arms providing perineal urethral compression [29]. In a 2014 multinational clinical trial, there was the first report of efficacy and safety for Virtue sling. In an initial trial, the sling was placed without fixation, and a subsequent cohort incorporated the fixation. At 12-month success ( $>50 \%$ decrease in 24 -hour pad weigh) rate was $42 \%$ in the group without fixation while $79 \%$ in the fixation group. These results suggest that fixation is an important process in Virtue sling. However, in the fixation group about $20 \%$ experienced mild genital paresthesia and $12.9 \%$ perineal pain. respectively [30]. The results of the long-term study of Virtue sling released in 2016 were somewhat negative outcomes. During the followup period of 55 months, $68 \%$ of patients experienced treatment failure. Due to pain and procedural failure, $22 \%$ of the patients removed the sling. In addition, $7 \%$ of patients complained of significant chronic pain [31].

\section{Advantages and Disadvantages of the Transobturator Retrourethral Sling}

Of the transobturator retrourethral sling devices, most studies reported on the AdVance sling, which has relatively good outcomes. In particular, good results can be expected in patients who have good residual sphincter function and those who have mild-to-moderate PPI. Overall, relatively few complications occur and most of them are mild.

One disadvantage is that adjustment is impossible after surgery, and the success rate of the surgery may not be good in pa- tients who previously had radiation treatment, those with severe PPI, or those who have a defect in the sphincter function.

\section{ADJUSTABLE SLING}

Adjustable slings are positioned on top of the bulbospongiosus muscle at the midurethra by a retropubic or transobturator approach. Nowadays, available devices are the Argus classic, Argus T, ATOMS, and Remeex. In general, surgical outcomes are comparable for all adjustable slings. However, there are differences in complications and adjustment techniques.

\section{Argus and Argus $\mathrm{T}$}

The concept of the Argus (Promedon, Córdoba, Argentina) was introduced first in 2006 and was designed to resolve incontinence, adjusting the tension of compressing the bulbar urethra. In an earlier phase, the Argus was designed to be placed via the retropubic approach; however, recently, the Argus T (Promedon) was changed to be placed through the obturator foramen. Both systems consist of 2 cone columns and 2 central pads for fixation. For each fixation arm, a washer is used so that they can be firmly fixed to the rectus sheath or fibromuscular tissue of the obturator foramen. The tension does not directly damage the urethra; however, it is important to control to the extent that the passive coaptation of the urethra is possible, and the appropriate tension can be decided, measuring the retrograde leak point pressure during the surgery.

Romano et al. [32] found that $73 \%$ of Argus patients were cured (dry, no pads) and 10\%, improved (mild, sporadic incon- 
Table 3. Summary of efficacy and complications following the Argus/Argus T male sling

\begin{tabular}{|c|c|c|c|c|c|c|c|c|c|}
\hline $\begin{array}{l}\text { Reference } \\
\text { No. }\end{array}$ & Device & No. & $\begin{array}{l}\text { Follow-up } \\
(\mathrm{mo})\end{array}$ & $\begin{array}{c}\text { Definition of } \\
\text { cure }\end{array}$ & $\begin{array}{c}\text { Cure } \\
\text { rate }(\%)\end{array}$ & $\begin{array}{l}\text { Definition of } \\
\text { improvement }\end{array}$ & $\begin{array}{l}\text { Improvement } \\
\text { rate }(\%)\end{array}$ & Adjustment & Complication \\
\hline [32] & Argus & 48 & 7.5 & No pad usage & 73 & $\begin{array}{l}\text { One or fewer pads } \\
\text { per day }\end{array}$ & 10 & - & $\begin{array}{l}6 \% \text { : urethral perforation } \\
10 \% \text { : explanation due to } \\
\text { erosion or infection } \\
\text { 15\%: transient urinary } \\
\text { retention }\end{array}$ \\
\hline [33] & Argus & 101 & 24.2 & No pad usage & 79.2 & - & - & $\begin{array}{c}39 \text { Cases } \\
(38.6 \%)\end{array}$ & $\begin{array}{l}\text { 15.8\%: explanation due to } \\
\text { erosion or infection } \\
14.9 \% \text { : transient perineal pain }\end{array}$ \\
\hline [34] & Argus & 100 & 27 & $\begin{array}{l}\text { No pad usage } \\
\text { or one pad } \\
\text { for security } \\
\text { reasons }\end{array}$ & 54 & $\begin{array}{l}\text { One or } 2 \text { pads per } \\
\text { day were used and } \\
\text { if there was a } \\
\text { reduction in daily } \\
\text { pad usage of } 50 \% \text {. }\end{array}$ & 18 & $\begin{array}{l}32 \text { Cases } \\
(32.0 \%)\end{array}$ & $\begin{array}{l}\text { Acute urinary retention }(n=16) \text {, } \\
\text { bladder perforation }(n=6) \text {, } \\
\text { temporary perineal pain }(n=9) \text {, } \\
\text { wound dehiscence }(n=6), \\
\text { persistent perineal pain }(n=5) \text {, } \\
\text { urethral stricture }(n=12), \\
\text { explantation due to infection, } \\
\text { erosion or pain }(n=11)\end{array}$ \\
\hline [35] & Argus & 29 & 35 & No pad usage & 17 & - & - & - & $\begin{array}{l}\text { 83\%: total complication rate } \\
35 \% \text { : acute urinary retention. } \\
\text { 35\%: explantation due to } \\
\text { urethral erosion }(n=3), \\
\text { infection }(n=2), \\
\text { system dislocation }(n=2), \\
\text { urinary retention }(n=2), \\
\text { and persistent pain }(n=1) \\
27 \% \text { : significant perineal pain }\end{array}$ \\
\hline [36] & Argus T & 31 & 30 & $\begin{array}{l}\text { No pad usage } \\
\text { or one pad } \\
\text { for security } \\
\text { reasons }\end{array}$ & 77 & $\begin{array}{l}\text { One wet pad per } \\
\text { day }\end{array}$ & 10 & 7 Cases & $\begin{array}{l}\text { 61\%: transient perineal pain } \\
\text { (2.8\%: persistent pain) } \\
5.6 \% \text { : infection } \\
5.6 \% \text { : transient urinary retention }\end{array}$ \\
\hline [37] & Argus T & 43 & 28.8 & $\begin{array}{l}0-5 \mathrm{~g} \text { in } 24-\mathrm{hr} \\
\text { pad weight } \\
\text { test }\end{array}$ & 61.9 & $\begin{array}{l}\text { Reduction of urine } \\
\text { loss in 24-hr pad } \\
\text { weight test }>50 \%\end{array}$ & 26.2 & $\begin{array}{l}\text { Median } \\
\text { adjustment } \\
\text { rate was } \\
1.7\end{array}$ & $\begin{array}{l}\text { Explantation due to pain or } \\
\text { ineffectiveness }(n=5) \text {, } \\
\text { persistent pain }(n=7) \text {, } \\
\text { postoperative urgency }(n=3) \text {, } \\
\text { and suprapubic wound } \\
\text { infection }(n=2)\end{array}$ \\
\hline
\end{tabular}

tinence, 1 or fewer pads/day); but the mean follow-up was short (7.5 months). Hübner et al. [33], in a study of 101 patients, reported $79.2 \%$ of patients achieved dryness after a mean followup of 2.1 years; $38.6 \%$ of the patients needed tension adjustment, and $15.8 \%$ had to remove the sling due to urethral erosion or infection. In this study, 33.7\% of the patients failed in a different type of SUI before Argus implantation, and $21.8 \%$ had radiation history, suggesting that it would be an effective treatment option for complicated patients. According to the results of a retrospective analysis of 100 with the Argus implant, the success rate was $72 \%$ in a median follow-up for 27 months [34]. Outcomes differed depending on the degree of preoperative in- continence. The success rate was $92 \%$ in patients with mild incontinence (1-2 pad per day [PPD]); $67 \%$ in moderate incontinence ( 3 to $5 \mathrm{PPD}$ ); and $67 \%$ in severe incontinence ( $>5 \mathrm{PPD}$ ). It was also reported that complications occurred in $38 \%, 57 \%$, and $59 \%$, respectively, in proportion to this. Due to refractory infection, erosion, sling rupture and pain, 11 patients had explanation. The overall complication rate was not low (55\%), but most were grades I to II, and especially, since prior radiation treatment, surgery for urethral stricture or bladder neck stenosis would be associated with treatment failure, it was suggested that attention should be paid [34]. However, around the same period, Dalpiaz et al. [35]. presented a somewhat negative re- 
sult. Immediately after the surgery, $79 \%$ of the patients were discharged in the cured (dry) state; however, in a median 35 -month follow-up, only $17 \%$ of the patients maintained the dry state. In addition, $83 \%$ of the patients experienced complications, and of this $53 \%$ were grade III. In addition, $35 \%$ of the patients had to get the device removed due to erosion, infection, dislocation, urinary retention, and persistent pain.

In 2008, Argus T was newly launched. It only differed in the implantation route and the position of the washers from the existing Argus but there is no difference in the sling itself. In 2014, Romano et al. [36] reported the result of a 30-month follow-up in which $77 \%$ of the patients were cured (dry, no pad) while $10 \%$ were improved (1 pad usage). These findings found that, according to the baseline degree of incontinence, $100 \%$ of mildto-moderate SUI patients were dry, while severe incontinence patients showed $71 \%$ of dry rate. Bauer et al. [37] conducted a prospective study with a median 28.8-month follow-up with 43 patients, and $61.9 \%$ of the patients were cured (dry), while $26.2 \%$ showed an improvement. The mean number of adjustments was $1.7(0-3)$. No patient experienced urinary retention, significant postresidual urine or erosion of the sling. Table 3 summarized efficacy and complications following the Argus and Argus T.

\section{ATOMS}

The ATOMS sling (A.M.I, Feldkirch, Austria) was introduced to Europe for the first time in 2008, and following modifications to the design and durability, the present device was designed, and was introduced for the first time as an adjustable transobturator hydraulic system on the market in 2009. This system consists of a mesh implant with an adjustable cushion, protection sheet and titanium port for adjustment of cushion volume. The silicone cushion is located at the center of the mesh and filled via the titanium port and catheter. Thus, it ensures an even distribution of pressure on the urethra. Patient-specific adjustment is performed by puncturing the port percutaneously and is possible at any time in an outpatient setting. Unlike AUS, since ATOMS compresses only the dorsal side of the bulbar urethra, ventral and lateral blood flows are intact. It is a device that has been designed to reduce suburethral atrophy $[38,39]$.

According to a study of 38 PPI patients, $60.5 \%$ were considered dry (0-1 PPD) and $23.7 \%$ improved (more than $1 \mathrm{PPD}$ but more than $50 \%$ decrease in pad usage). After surgery, $89.5 \%$ of the patients needed further adjustments, and 3.97 adjustments were conducted on average [38]. In a multicenter study conducted in 99 moderate to severe incontinence patients with an average follow-up time of 17.8 months, $63 \%$ were considered dry (0 PPD and $<10 \mathrm{~mL}$ in 24-hour pad test) and 29\% were improved (daily pad use reduced by $>50 \%$, or patients needed 1-2 PPD and 10-40 $\mathrm{mL}$ in 24-hour pad test). The mean number of adjustments was 3.8 (range, 1-6). However, 68.7\% of the patients complained of perineal and scrotal pains, and explanation due to port infection occurred in up to $10.5 \%$. Patients who previously had radiation treatment or had undergone surgery for incontinence showed comparable outcomes to those who had not [39]. In 2017, the long-term outcome of 287 ATOMO sling PPI patients was reported. Three adjustments were conducted on average during the median 31-month follow-up. The overall success rate was $90 \%$, and the dry rate was $64 \%$. In the final follow-up, $80 \%$ of the ATOMS devices were still functioning. The device was removed in $20 \%$ of the patients due to titanium intolerance (41\%), leak/dysfunction (30\%), early infection ( $\leq 30$ days; $11 \%$ ), late infection ( $>30$ days; $11 \%$ ), dislocation (5\%), and persistent pain (2\%). In total, $23 \%$ of patients had a history of radiation treatment, and $20 \%$ had undergone incontinence surgery. Primary implantation $(\mathrm{P}=0.002)$, good physical health $(\mathrm{P}=0.001)$, and no history of radiation treatment $(\mathrm{P}<0.001)$ were prognostic factors for good surgical outcomes [40]. Table 4 summarized efficacy and complications following the ATOMS.

\section{Remeex}

The Remeex (Neomedic International, Terrassa, Spain) device consists of a polypropylene mesh with 2 nonabsorbable traction threads and a regulation device (varitensor) which is a subcutaneous permanent implant. The varitensor is placed over the abdominal rectum fascia $2 \mathrm{~cm}$ above the pubis; the implant allows adjustment of suburethral pressure from outside the body by means of an external manipulator. In a multicenter study of 51 male patients, $65 \%$ were dry (0 or security pad) and $20 \%$ was improved (50\% reduction in pad usage) at a median follow-up 32 months. In 1-4 months after surgery, in 44 patients, the manipulation of varitensor was conducted under local anesthesia. In one case, urethral erosion occurred, and the sling was removed, and 2 patients had the varitensor removed due to infection. Many patients complained of perineal pain or discomfort. Satisfaction was $78 \%$ in patients who had severe incontinence at baseline, which was lower than that of mild-to-moderate incontinence patients (100\% and $90 \%$, respectively). In addition, the satisfaction of patients who had previously had radiation 
Table 4. Summary of efficacy and complications following the ATOMS and Remeex male sling

\begin{tabular}{|c|c|c|c|c|c|c|c|c|c|}
\hline $\begin{array}{l}\text { Reference } \\
\text { No. }\end{array}$ & Device & No. & $\begin{array}{l}\text { Follow-up } \\
\quad(\mathrm{mo})\end{array}$ & $\begin{array}{l}\text { Definition of } \\
\text { cure }\end{array}$ & $\begin{array}{c}\text { Cure } \\
\text { rate }(\%)\end{array}$ & $\begin{array}{l}\text { Definition of } \\
\text { improvement }\end{array}$ & $\begin{array}{l}\text { Improvement } \\
\text { rate }(\%)\end{array}$ & Adjustment & Complication \\
\hline [38] & ATOMS & 38 & 16.9 & None or 1 PPD & 60.5 & $\begin{array}{l}\text { A reduction of } \\
\text { pads 50\% }\end{array}$ & 23.7 & $\begin{array}{l}\text { Mean number of } \\
\text { adjustments: } 3.97\end{array}$ & Not assessed \\
\hline [39] & ATOMS & 99 & 17.8 & No pad usage & 63 & $\begin{array}{l}\text { One or } 2 \text { pads per } \\
\text { day were used and } \\
\text { if there was a } \\
\text { reduction of } \\
\text { pads } 50 \%\end{array}$ & 29 & $\begin{array}{l}\text { Mean number of } \\
\text { adjustments: } 3.8\end{array}$ & $\begin{array}{l}\text { 68.7\%: transient } \\
\text { perineal/scrotal } \\
\text { dysesthesia or pain } \\
4 \% \text { : wound infection } \\
\text { 2\%: transient } \\
\text { urinary retention } \\
\text { No urethral or } \\
\text { bladder injuries }\end{array}$ \\
\hline$[40]$ & ATOMS & 287 & 31 & $\begin{array}{l}\text { None or } 1 \text { PPD } \\
\text { (dry rate) }\end{array}$ & 64 & $\begin{array}{l}\text { Improvement in } \\
\text { daily pad test and } \\
\text { pad use (overall } \\
\text { success rate) }\end{array}$ & 90 & $\begin{array}{l}\text { Median number of } \\
\text { adjustments: } 3.0\end{array}$ & $\begin{array}{l}20 \%: \text { explantation }^{\text {a) }} \\
3 \% \text { : transient } \\
\text { urinary retention } \\
2 \%: \text { early infection } \\
2 \%: \text { hematoma }\end{array}$ \\
\hline [41] & Remeex & 51 & 32 & None or 1 PPD & 64.70 & $\begin{array}{l}\text { A reduction of } \\
\text { pads } 50 \%\end{array}$ & 19.6 & - & $\begin{array}{l}\text { 9.8\%: bladder } \\
\text { perforation } \\
5.9 \% \text { : mild perineal } \\
\text { hematoma }\end{array}$ \\
\hline
\end{tabular}

PPD, pad per day.

${ }^{a)}$ Etiologies of explanation: titanium intolerance (41\%), leak (21\%), early infection (11\%), late infection (11\%), dysfunction (9\%), dislocation (5\%), and persistent pain (2\%).

treatment was lower than that of those who did not $(60.0 \%$ vs. 90.2\%) (Table 4) [41].

In mid-2011, Remeex System, there was a change in the device to decrease the number of times of adjustment, and it came to be available in the name of MRS-II. The biggest change was the increase of the size of the base plate, and accordingly, it was designed to put the traction thread in a more lateral position. Since it was possible to maintain a straight line in a position spatially more distant from the bladder, ultimately, the thread tension loss could be reduced, and continence could be maintained well. In 2016, the long-term outcomes of MRS-II for 40.7 months was announced in Spain, the number of times of adjustment was 2.4 times, on average, which was significantly lower than the number of times of adjustment of 3.1 times on average in classic MRS. As for efficacy, 39\% of patients used safety pad only when they would do high-intensity exercises, but dryness was maintained in all patients [42].

\section{Advantages and Disadvantages of Adjustable sling}

The biggest advantage is that tension adjustment is possible any time even after surgery. It shows good results in patients with severe PPI and those who have previously had radiation treat- ment. However, the adjustable sling overall has a high complication rate, and not a few explanations are conducted.

\section{PROPER PATIENT SELECTION FOR MALE SLING DEVICE}

There is no universally accepted standard for the type of male sling for patients with persistent PPI. In addition, there are a few studies comparing individual slings, and each study has a different standard for the definition of "cure" and "improvement" after sling implantation. Thus, it is not possible to compare directly reported outcomes and complications and it is not possible to identify 1 sling procedure as superior over another. In general, the decision on what treatment to choose usually follows contraindication such as severe incontinence or previous history of radiation treatment.

The ideal population for the transobturator retrourethral sling is still controversial, but generally, it is considered to have a good effect on patients who complain of mild-to-moderate incontinence. The problem, however, is how to evaluate the severity of baseline incontinence status accurately. Some urologists use daily pad usage or urine loss volume through a pad 
test as standards; however, it is very inaccurate, and it is hard to measure the symptoms accurately. Another group insists on the usefulness of preoperative "repositioning test" for male incontinence patients $[8,22,43,44]$. Repositioning of the posterior urethra is performed by applying a gentle midperineal pressure parallel to the anal canal and below the bulbar urethra at rest and during voluntary contraction of the pelvic floor. Positive results in this test include: if the sphincter closes autonomously, reflex, concentrically and complete closure during repositioning of the posterior urethra, and if the functional urethra length (=coaptive zone) during active sphincter contraction (circumferential coaptation of the membranous urethra) is $\geq 1 \mathrm{~cm}$ [43]. In other words, for patients who have some remaining sphincter function and movable posterior urethra, fixed slings like AdVance are useful.

Adjustable slings can be utilized in patients with all severities of incontinence and can be applied to patients who cannot have AUS or reject it. In addition, it is an option that can be used without a high risk in patients who have had previous radiation treatment.

\section{AUTHOR CONTRIBUTION STATEMENT}

- Full access to all the data in the study and takes responsibility for the integrity of the data and the accuracy of the data analysis: $K J K, S T C$

-Study concept and design: STC

- Acquisition of data: $K J K, S J K$

- Analysis and interpretation of data: $K J K$

- Drafting of the manuscript: KJK

- Critical revision of the manuscript for important intellectual content: STC

- Administrative, technical, or material support: SJK

- Study supervision: STC

\section{REFERENCES}

1. Ficarra V, Novara G, Rosen RC, Artibani W, Carroll PR, Costello A, et al. Systematic review and meta-analysis of studies reporting urinary continence recovery after robot-assisted radical prostatectomy. Eur Urol 2012;62:405-17.

2. Crivellaro S, Morlacco A, Bodo G, Agro' EF, Gozzi C, Pistolesi D, et al. Systematic review of surgical treatment of post radical prostatectomy stress urinary incontinence. Neurourol Urodyn 2016;35:87581.
3. Kaufman JJ. Urethral compression operations for the treatment of post-prostatectomy incontinence. J Urol 1973;110:93-6.

4. Schaeffer AJ, Clemens JQ, Ferrari M, Stamey TA. The male bulbourethral sling procedure for post-radical prostatectomy incontinence. J Urol 1998;159:1510-5.

5. Chong JT, Simma-Chiang V. A historical perspective and evolution of the treatment of male urinary incontinence. Neurourol Urodyn 2018;37:1169-75.

6. Cornu JN, Sèbe P, Ciofu C, Peyrat L, Beley S, Tligui M, et al. The AdVance transobturator male sling for postprostatectomy incontinence: clinical results of a prospective evaluation after a minimum follow-up of 6 months. Eur Urol 2009;56:923-7.

7. Rehder P, Mitterberger MJ, Pichler R, Kerschbaumer A, Glodny B. The 1 year outcome of the transobturator retroluminal repositioning sling in the treatment of male stress urinary incontinence. BJU Int 2010;106:1668-72.

8. Bauer RM, Soljanik I, Füllhase C, Buchner A, May F, Stief CG, et al. Results of the AdVance transobturator male sling after radical prostatectomy and adjuvant radiotherapy. Urology 2011;77:474-9.

9. Cornu JN, Sèbe P, Ciofu C, Peyrat L, Cussenot O, Haab F. Midterm evaluation of the transobturator male sling for post-prostatectomy incontinence: focus on prognostic factors. BJU Int 2011;108: 236-40.

10. Soljanik I, Becker AJ, Stief CG, Gozzi C, Bauer RM. Urodynamic parameters after retrourethral transobturator male sling and their influence on outcome. Urology 2011;78:708-12.

11. Rehder P, Haab F, Cornu JN, Gozzi C, Bauer RM. Treatment of postprostatectomy male urinary incontinence with the transobturator retroluminal repositioning sling suspension: 3-year followup. Eur Urol 2012;62:140-5.

12. Soljanik I, Gozzi C, Becker AJ, Stief CG, Bauer RM. Risk factors of treatment failure after retrourethral transobturator male sling. World J Urol 2012;30:201-6.

13. Collado Serra A, Resel Folkersma L, Domínguez-Escrig JL, Gómez-Ferrer A, Rubio-Briones J, Solsona Narbón E. AdVance/AdVance XP transobturator male slings: preoperative degree of incontinence as predictor of surgical outcome. Urology 2013;81:1034-9.

14. Torrey R, Rajeshuni N, Ruel N, Muldrew S, Chan K. Radiation history affects continence outcomes after advance transobturator sling placement in patients with post-prostatectomy incontinence. Urology 2013;82:713-7.

15. Bauer RM, Kretschmer A, Stief CG, Füllhase C. AdVance and AdVance XP slings for the treatment of post-prostatectomy incontinence. World J Urol 2015;33:145-50.

16. Kowalik CG, DeLong JM, Mourtzinos AP. The advance transobtu- 
rator male sling for post-prostatectomy incontinence: subjective and objective outcomes with 3 years follow up. Neurourol Urodyn 2015;34:251-4.

17. Habashy D, Losco G, Tse V, Collins R, Chan L. Mid-term outcomes of a male retro-urethral, transobturator synthetic sling for treatment of post-prostatectomy incontinence: impact of radiotherapy and storage dysfunction. Neurourol Urodyn 2017;36:1147-50.

18. Hüsch T, Kretschmer A, Thomsen F, Kronlachner D, Kurosch M, Obaje A, et al. The AdVance and AdVanceXP male sling in urinary incontinence: is there a difference? World J Urol 2018;36:1657-62.

19. Zuckerman JM, Edwards B, Henderson K, Beydoun HA, McCammon KA. Extended outcomes in the treatment of male stress urinary incontinence with a transobturator sling. Urology 2014;83: 939-45.

20. Davies TO, Bepple JL, McCammon KA. Urodynamic changes and initial results of the AdVance male sling. Urology 2009;74:354-7.

21. Suskind AM, Bernstein B, Murphy-Setzko M. Patient-perceived outcomes of the AdVance sling up to 40 months post procedure. Neurourol Urodyn 2011;30:1267-70.

22. Bauer RM, Grabbert MT, Klehr B, Gebhartl P, Gozzi C, Homberg $\mathrm{R}$, et al. 36-month data for the AdVance $\mathrm{XP}^{\circledR}$ male sling: results of a prospective multicentre study. BJU Int 2017;119:626-30.

23. Grise P, Geraud M, Geraud M, Lienhart J, Le Portz B, Bubenheim $\mathrm{M}$, et al. Transobturator male sling TOMS for the treatment of stress post-prostatectomy incontinence, initial experience and results with one year's experience. Int Braz J Urol 2009;35:706-13.

24. Yiou R, Loche CM, Lingombet O, Abbou C, Salomon L, de la Taille A, et al. Evaluation of urinary symptoms in patients with postprostatectomy urinary incontinence treated with the male sling TOMS. Neurourol Urodyn 2015;34:12-7.

25. Yiou R, Bütow Z, Parisot J, Lingombet O, Augustin D, de la Taille A, et al. Update on 2-year outcomes of the TOMS ${ }^{\mathrm{TM}}$ transobturator male sling for the treatment of male stress urinary incontinence. Neurourol Urodyn 2016;35:44-7.

26. Grise P, Vautherin R, Njinou-Ngninkeu B, Bochereau G, Lienhart J, Saussine C, et al. I-STOP TOMS transobturator male sling, a minimally invasive treatment for post-prostatectomy incontinence: continence improvement and tolerability. Urology 2012;79:458-63.

27. Malval B, Rebibo JD, Baron M, Nouhaud FX, Pfister C, Cornu JN, et al. Long-term outcomes of I-Stop TOMS ${ }^{\mathrm{TM}}$ male sling implantation for post-prostatectomy incontinence management. Prog Urol 2017;27:1084-90.

28. Galiano M, Guillot-Tantay C, Sivaraman A, Slaoui H, Barret E, Rozet F, et al. Superficial implantation of the I-Stop TOMS transobturator sling in the treatment of postprostatectomy urinary in- continence: description of a novel technique and 1-year outcomes. Urology 2016;90:195-8.

29. Comiter CV, Nitti V, Elliot C, Rhee E. A new quadratic sling for male stress incontinence: retrograde leak point pressure as a measure of urethral resistance. J Urol 2012;187:563-8.

30. Comiter CV, Rhee EY, Tu LM, Herschorn S, Nitti VW. The virtue sling--a new quadratic sling for postprostatectomy incontinence-results of a multinational clinical trial. Urology 2014;84:433-8.

31. McCall AN, Rivera ME, Elliott DS. Long-term follow-up of the virtue quadratic male sling. Urology 2016;93:213-6.

32. Romano SV, Metrebian SE, Vaz F, Muller V, D’Ancona CA, Costa DE Souza EA, et al. An adjustable male sling for treating urinary incontinence after prostatectomy: a phase III multicentre trial. BJU Int 2006;97:533-9.

33. Hübner WA, Gallistl H, Rutkowski M, Huber ER. Adjustable bulbourethral male sling: experience after 101 cases of moderate-tosevere male stress urinary incontinence. BJU Int 2011;107:777-82.

34. Bochove-Overgaauw DM, Schrier BP. An adjustable sling for the treatment of all degrees of male stress urinary incontinence: retrospective evaluation of efficacy and complications after a minimal followup of 14 months. J Urol 2011;185:1363-8.

35. Dalpiaz O, Knopf HJ, Orth S, Griese K, Aboulsorour S, Truss M. Mid-term complications after placement of the male adjustable suburethral sling: a single center experience. J Urol 2011;186:604-9.

36. Romano SV, Huebner W, Rocha FT, Vaz FP, Muller V, Nakamura F. A transobturator adjustable system for male incontinence: 30-month follow-up of a multicenter study. Int Braz J Urol 2014; 40:781-9.

37. Bauer RM, Rutkowski M, Kretschmer A, Casuscelli J, Stief CG, Huebner W. Efficacy and complications of the adjustable sling system ArgusT for male incontinence: results of a prospective 2-center study. Urology 2015;85:316-20.

38. Seweryn J, Bauer W, Ponholzer A, Schramek P. Initial experience and results with a new adjustable transobturator male system for the treatment of stress urinary incontinence. J Urol 2012;187:95661.

39. Hoda MR, Primus G, Fischereder K, Von Heyden B, Mohammed $\mathrm{N}$, Schmid N, et al. Early results of a European multicentre experience with a new self-anchoring adjustable transobturator system for treatment of stress urinary incontinence in men. BJU Int 2013;111:296-303.

40. Friedl A, Mühlstädt S, Zachoval R, Giammò A, Kivaranovic D, Rom M, et al. Long-term outcome of the adjustable transobturator male system (ATOMS): results of a European multicentre study. BJU Int 2017;119:785-92. 
41. Sousa-Escandón A, Cabrera J, Mantovani F, Moretti M, Ioanidis E, Kondelidis N, et al. Adjustable suburethral sling (male remeex system) in the treatment of male stress urinary incontinence: a multicentric European study. Eur Urol 2007;52:1473-9.

42. Navalón-Monllor V, Ordoño-Domínguez F, Pallás-Costa Y, VilarCastro LA, Monllor-Peidro ME, Juan-Escudero J, et al. Long-term follow-up for the treatment of male urinary incontinence with the Remeex system. Actas Urol Esp 2016;40:585-91.
43. Bauer RM, Gozzi C, Roosen A, Khoder W, Trottmann M, Waidelich R, et al. Impact of the 'repositioning test' on postoperative outcome of retroluminar transobturator male sling implantation. Urol Int 2013;90:334-8.

44. Bauer RM, Mayer ME, Gratzke C, Soljanik I, Buchner A, Bastian PJ, et al. Prospective evaluation of the functional sling suspension for male postprostatectomy stress urinary incontinence: results after 1 year. Eur Urol 2009;56:928-33. 